\title{
The Effect of Humic Acid Substances on the Thyroid Function and Structure in Lead Poisoning
}

http://dx.doi.org/10.1590/1806-9061-2016-0299

\section{-Author(s)}

\section{Sahin $A^{\prime}$}

Iskender $\mathrm{H}^{\prime \prime}$

Terim Kapakin KA"II

Altinkaynak KIV

Hayirli $A^{v}$

Gonultas Av

Kaynar OVII

Department of Physiology, Faculty of Medicine, Ordu University, Ordu, Turkey

" Department of Nutrition and Dietetics, Faculty of Healthy Sciences, Artvin Coruh University, Artvin, Turkey

III Department of Pathology, Faculty of Veterinary Medicine, Ataturk University, Erzurum, Turkey

iv Clinical Biochemistry, Regional Research and Training Hospital, Erzurum, Turkey

$\checkmark$ Department of Animal Nutrition and Nutritional Disorders, Faculty of Veterinary Medicine, Ataturk University, Erzurum, Turkey

vı ITekirdag Public Hospital, Tekirdag, Turkey

VII Department of Biochemistry, Faculty of Veterinary Medicine, Ataturk University, Erzurum, Turkey.

\section{nail Address}

Corresponding author e-mail address Hatice Iskender

Department of Nutrition and Dietetics, Faculty of Healthy Sciences, Artvin Coruh University, Artvin/Turkey

Zip code: 08100

Tel: $\quad$ (+90466)2151063/2121

Email: haticeiskender2011@hotmail.com

\section{aKeywords}

Lead poisoning, humic acid substances, thyroid gland, chicken.

\section{ABSTRACT}

Lead $(\mathrm{Pb})$ is a heavy metal, which adversely affects thyroid gland function and structure. Due to its high molecular weight and abundant functional groups, humic acid substances (HAS) can form chelates with heavy metals. The experiment was conducted to evaluate the prophylactic effect of HAS on thyroid hormone levels and histopathological lesions of laying hens exposed to lead $(\mathrm{Pb})$ poisoning. After a week of adaptation, 192 Lohmann White laying hens (25 weeks of age) were fed one of four diets: a basal diet (BD) or the BD with HAS $(0.15 \%)$, with $\mathrm{Pb}(0.3$ $\mathrm{g} / \mathrm{kg}$ ), or with both. Experimental groups were replicated in 12 cages, with four hens each. $\mathrm{Pb}$ poisoning did not alter triiodothyronine $\left(\mathrm{FT}_{3}\right.$; $3.22 \pm 0.20 \mathrm{ng} / \mathrm{dL})$ or thyroxine $\left(\mathrm{FT}_{4} ; 0.71 \pm 0.08 \mathrm{ng} / \mathrm{dL}\right)$ concentrations, but caused a $167 \%$ increase in thyroid stimulating hormone (TSH) concentration. HAS supplementation returned the high TSH levels of hens exposed to Pb poisoning to normal values. Degenerative changes in the epithelial cells of the thyroid gland of the hens exposed to $\mathrm{Pb}$ poisoning were evidenced. Connective tissue cells in the interfollicular area and total amount of colloids with partially atrophic follicles were observed. These histopathological findings were less severe when HAS was added to the diet. In conclusion, HAS alleviates the effects of $\mathrm{Pb}$ poisoning on thyroid gland function and structure, possibly preventing its internalization by the tissue by forming chelates and exerting antiinflammatory effects.

\section{INTRODUCTION}

The thyroid gland mediates various metabolic processes in the body by secreting mainly thyroxine $\left(T_{4}\right)$ and triiodothyronine $\left(T_{3}\right)$ hormones. These hormones are derived from amino acids, and result from the iodination of thyroglobulin tyrosine residues. They are responsible for regulating the global metabolic activity of the body. The secretion of thyroid hormones is controlled by the thyroid-stimulating hormone (TSH) that is released from the anterior pituitary gland. Increased activity of the thyroid gland results in hyperthyroidism, whereas decreased activity results in hypothyroidism (Szkudlinski et al., 2002). Environmental, physiological, and genetic factors play a role in the development of both hyperthyroidism and hypothyroidism (Burger, 2004). The exposure to heavy metals is of the most important environmental factor that adversely affects the function of the thyroid gland (Cullent et al., 1984).

Lead $(\mathrm{Pb})$ is one of the main heavy metals and non-essential toxic elements, and pose a risk to public health due to expanded urbanization and increased industrialization (Smith, 1984; Roper, 1991; Tong et al., 2000). It is widespread in nature and has been used in many industrial applications throughout history, such as manufacturing of batteries, some paints, glass, construction materials, agrochemicals, cosmetics, 
Sahin A, Iskender H, Terim Kapakin KA, Altinkaynak K, Hayirli A, Gonultas A, Kaynar 0
The Effect of Humic Acid Substances on the Thyroid Function and Structure in Lead Poisoning and fuel additives (Elwood et al., 1984). Once taken into the body through different routes, $\mathrm{Pb}$ accumulates in the organs and tissues. In the bloodstream, 85-90\% of $\mathrm{Pb}$ is bound to erythrocytes, and the remaining 15-10\% to plasma proteins (Lyn Patrick, 2006). Lead poisoning causes hematological, neurological, circulatory, and immunological pathologies, accompanied by biochemical changes, liver and kidney dysfunctions, and disrupt glucose metabolism (Al-Saleh, 1994; Lavicoli et al., 2003). Pb poisoning adversely affects endocrine glands, particularly the homeostasis of thyroid hormones, reproductive hormones and stress hormones (Zacharewski, 1998).

Chelating agents are used for the treatment of heavy metal poisoning. Humic acid substances (HAS) are water soluble, and include humic, fluvic, and ulmic acids derived from humus, breakdown product of organic substances in the soil (Islam et al., 2005). Previous studies have shown that humic acid regulates abnormal thyroid hormone secretion and act as immunomodulators (Laurberg et al., 2003). Due to their high molecular weight and functional groups (Schnitzer and Khan, 1972; Fan et al., 2004), it was hypothesized that supplementing diets with HAS reduces the adverse effect of heavy metals on the endocrine functions through forming chelates. This preliminary experiment was conducted to evaluate the prophylactic effect of supplementing HAS on hormonal and histopathological changes in the thyroid gland in laying hens exposed to $\mathrm{Pb}$ poisoning.

\section{MATERIALS AND METHODS}

\section{Animals, diets and experimental design}

A total of 192 Lohmann White laying hens of 25 weeks of age randomly were assigned to one of the four dietary treatments.

A week before introducing the dietary treatments, all birds were fed the same iso-nitrogenous and isoenergy basal diet formulated to meet their nutritional requirements (NRC, 1994). Birds were then fed a basal diet, or the basal diet with $0.15 \%$ HAS $(50.6 \%$ humic acid, 9.4\% fulvic acid) (Farmagülatör $X P$, Farmavet International, Istanbul, Turkey), $0.3 \mathrm{~g} \mathrm{~Pb} / \mathrm{kg}$ (lead acetate trihydrate, Acros Organics, New Jersey, USA), or the same levels of $\mathrm{Pb}+\mathrm{HAS}$.

Each treatment ( $\mathrm{n}=48$ birds) was replicated in 12 cages $(42 \times 48 \mathrm{~cm})$, housing four hens each. The experiment lasted 10 days. During the adaptation and experimental periods, hens were subjected to a light regimen of 17L:7D. Feed and fresh water were provided ad libitum.

\section{Blood sampling and biochemistry}

At the end of the experiment, blood samples were collected from axillary veins of one randomly selected hen per cage ( $n=12$ per treatment) into additive-free blood tubes. Blood samples were centrifuged at 1,500 $g$ for 15 min, and sera were placed in Eppendorf tubes. The sera $(250 \mu \mathrm{l})$ were first digested with a mixture of $2 \mathrm{~mL} \mathrm{HNO}_{3}$ (30\%; Merck-KGaA, Darmstadt, Germany) and $3 \mathrm{~mL} \mathrm{H}_{2} \mathrm{O}_{2}(70 \%$, Merck-KGaA) in a Microwave Digestion System (Berghoff, Eningen, Germany) for $25 \mathrm{~min}$. The specimens were then subjected to analysis of elemental $\mathrm{Pb}$ using Inductively Coupled Plasma Emission Spectroscopy (Optima 2100 DV, ICP/ OES, Perkin-Elmer, Shelton, CT). Moreover, the sera were analyzed for T3, T4, and TSH levels using a diagnostic automatic analyzer (Modular Analytics Evo, F. Hoffmann-La Roche Ltd., Berlin, Germany).

\section{Histopathology}

After blood sampling, birds were sacrificed by cervical dislocation for harvesting the thyroid glands. Tissue samples were fixed in 10\% buffered formaldehyde. Fixed tissues were embedded in paraffin blocks. The sections $(5 \mu)$ were stained with hematoxylin eosin $(\mathrm{HxE})$, and evaluated under a light microscope after performing Masson's Trichrome and Periodic Acid Shift staining methods.

\section{Statistics}

Data were analyzed by one-way analysis of variance using the PROC GLM procedure (SAS, 2002). Statistical differences among group means were determined by the LSD option and considered significant at $p \leq 0.05$. Data were presented as least square mean \pm standard error of the mean $(\mathrm{LSM} \pm \mathrm{SEM})$.

\section{RESULTS}

\section{Serum lead and thyroid hormone levels}

Table 1 summarizes serum $\mathrm{Pb}$ and thyroid hormone level results. The addition of $\mathrm{Pb}$ in the basal diet caused a 3.73-fold increase in serum $\mathrm{Pb}$ level compared with the control group $(p<0.0001)$. HAS supplementation decreased serum $\mathrm{Pb}$ level by $16.5 \%$ compared with the $\mathrm{Pb}$-poisoned group $(\mathrm{p}<0.05)$.

Serum $\mathrm{FT}_{4}$ level $(0.71 \mathrm{ng} / \mathrm{dL})$ and $\mathrm{FT}_{3}: \mathrm{FT}_{4}$ ratio (5.49) were similar across the experimental groups. Lead poisoning caused a 2.67-fold increase in TSH level $(p<0.05)$, and was suppressed by HAS supplementation to the control level. 
Sahin A, Iskender H, Terim Kapakin KA, Altinkaynak K, Hayirli A, Gonultas A, Kaynar $\mathrm{O}$

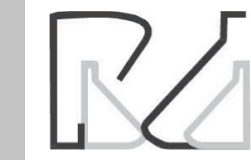

Table 1 - Effects of the dietary supplementation of humic acid substances (HAS) on serum lead and thyroid hormone levels of laying hens exposed to a 10-day lead $(\mathrm{Pb})$ poisoning.

\begin{tabular}{lccccc}
\hline & \multicolumn{5}{c}{ Experimental Groups } \\
\cline { 2 - 5 } Variable & Control & HAS $(0.15 \%)$ & $\mathrm{Pb}(0.3 \mathrm{~g} / \mathrm{kg})$ & $\mathrm{Pb}+\mathrm{HAS}$ & SEM \\
\hline $\mathrm{Pb}, \mathrm{mg} / \mathrm{L}$ & $0.062^{\mathrm{c}}$ & $0.068^{\mathrm{c}}$ & $0.231^{\mathrm{a}}$ & $0.193^{\mathrm{b}}$ & 0.04 \\
$\mathrm{FT}_{3^{\prime}} \mathrm{pg} / \mathrm{mL}$ & $2.94^{\mathrm{b}}$ & $3.30^{\mathrm{ab}}$ & $3.22^{\mathrm{ab}}$ & $3.67^{\mathrm{a}}$ & 0.08 \\
$\mathrm{FT}_{4^{\prime}} \mathrm{ng} / \mathrm{dL}$ & 0.715 & 0.682 & 0.719 & 0.726 & 0.20 \\
$\mathrm{FT}_{3}: \mathrm{FT}_{4}$ & 4.34 & 5.80 & 4.79 & 7.04 & 0.89 \\
$\mathrm{TSH}_{1} \mu \mathrm{IU} / \mathrm{L}$ & $0.003^{\mathrm{b}}$ & $0.005^{\mathrm{b}}$ & $0.008^{\mathrm{a}}$ & $0.004^{\mathrm{b}}$ & 0.001 \\
\hline
\end{tabular}

"Data are the least square mean \pm standard error of the mean (SEM) ( $n=12$ cages per group, 4 hens per cage). Different superscripts within the same rows differ $(p<0.05)$.

\section{Thyroid Gland Histopathology}

The thyroid tissues of the control hens did not show any histopathological changes (Figure 1). In the hens exposed to $\mathrm{Pb}$ poisoning, degenerative changes and necrotic areas were evident in the epithelial cells of the thyroid gland at various degrees of intensity (Figure 2A). Increases in connective tissue cell numbers in the interfollicular area and in the total amount of colloid with atrophic follicles were observed. Moreover, mononuclear cell infiltration, particularly lymphocytes in thyroid parenchyma and capsule and its surrounding fat tissue were evident (Figure 2B).

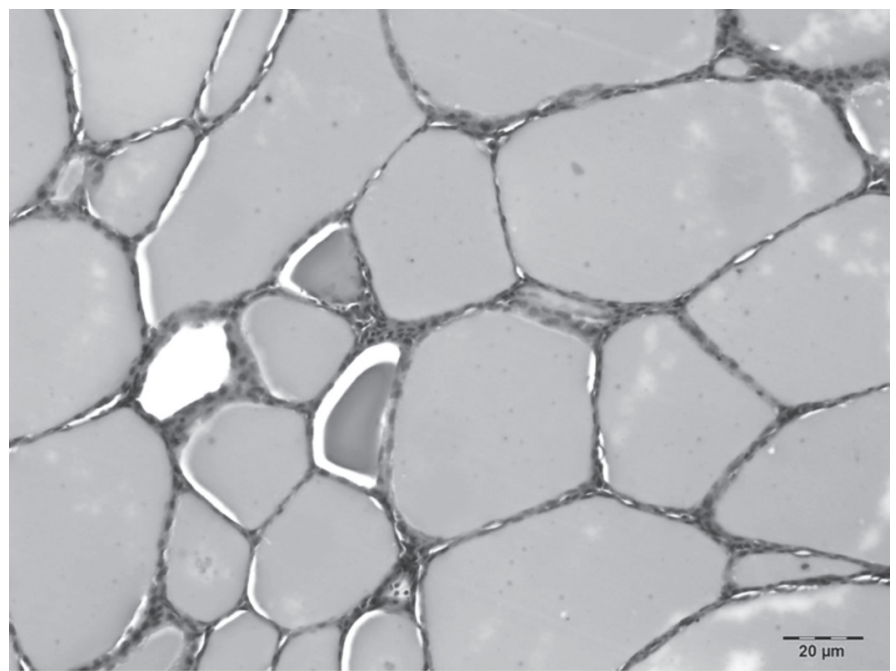

Figure 1 - The appearance of a normal thyroid gland (Control Group) (H\&E).

Similar histopathological lesions were observed in the hens that were fed $\mathrm{Pb}+\mathrm{HAS}$, but at a lesser intensity. Follicular structure disappeared and colloid structure spreaded around to parenchymal and interfollicular areas in three cases (Figure 3A). In other cases, lesions were reduced and follicles presented normal histological appearance (Figure 3B).
The Effect of Humic Acid Substances on the Thyroid Function and Structure in Lead Poisoning
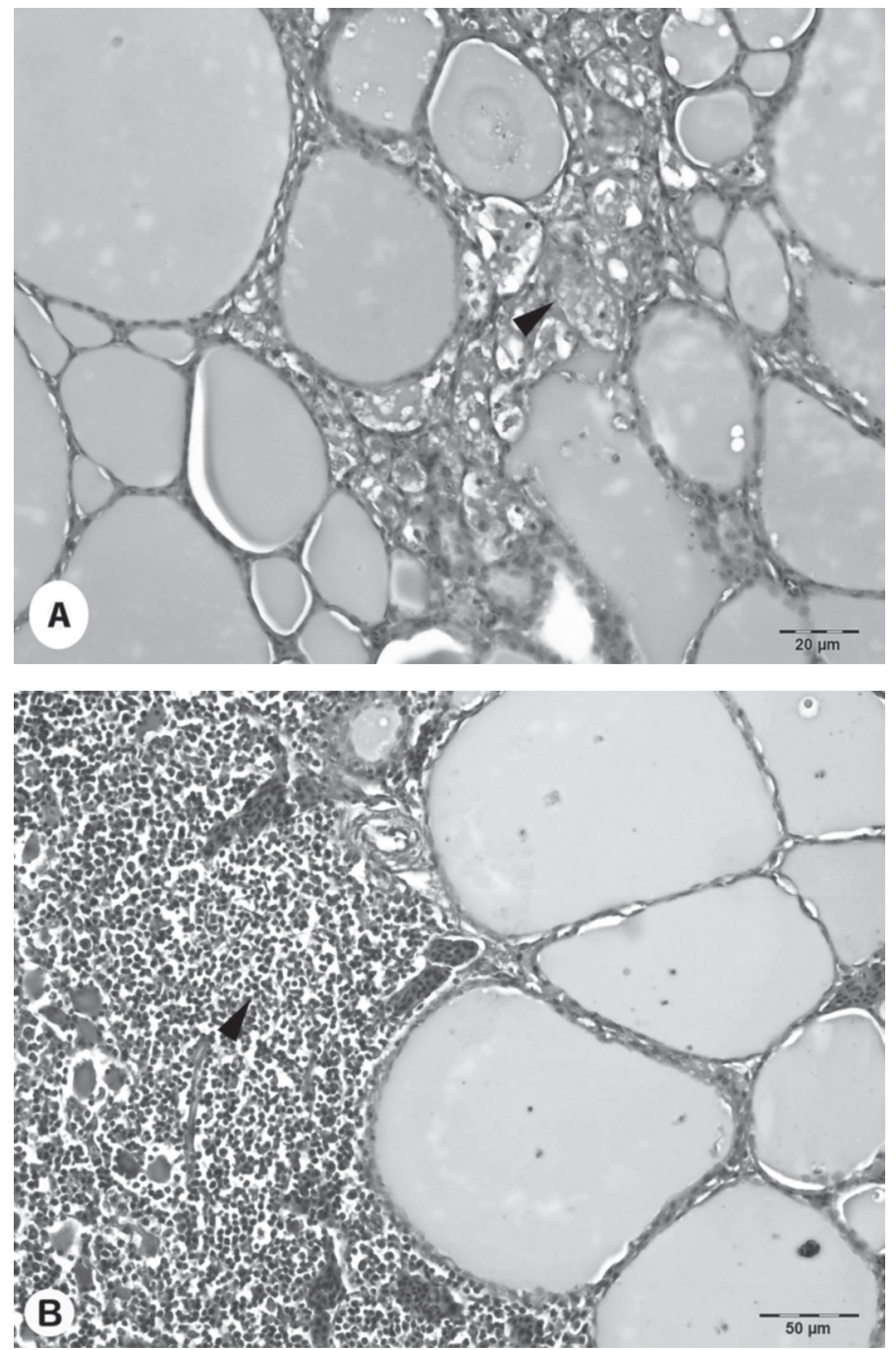

Figure 2 - Degenerative changes with debris and necrotic areas (arrowhead) (H\&E) (Panel A) and lymphocyte infiltrations (arrowhead) (H\&E) (Panel B) in the thyroid gland (Lead Group).

\section{DISCUSSION}

Lead is one of the most harmful heavy metals and can accumulate in soft (i.e., liver, kidney) and hard (e.g., bone) tissues (Lyn Patrick, 2006; Gillis et al., 2012). Lead poisoning causes structural and functional changes in many organs, such as renal dysfunction, nervous system disorders, glucose metabolism abnormalities, liver dysfunctions, and hematological changes (AlSaleh 1994; Lavicoli et al., 2003). In particular, it may cause anemia by reducing hemoglobin concentration in the hematologic system (Hilliard et al., 1973; Lynch et al., 1976).

Several agrochemicals are applied in crop production, and many poultry feedstuffs may be contaminated by environmental pollution. Lead can accumulate in the body, which may adversely affect animal health and pose a food safety risk. The $\mathrm{Pb}$ level of $0.3 \mathrm{~g} / \mathrm{kg}$ diet 
Sahin A, Iskender H, Terim Kapakin KA, Altinkaynak K, Hayirli A, Gonultas A, Kaynar 0
The Effect of Humic Acid Substances on the Thyroid Function and Structure in Lead Poisoning
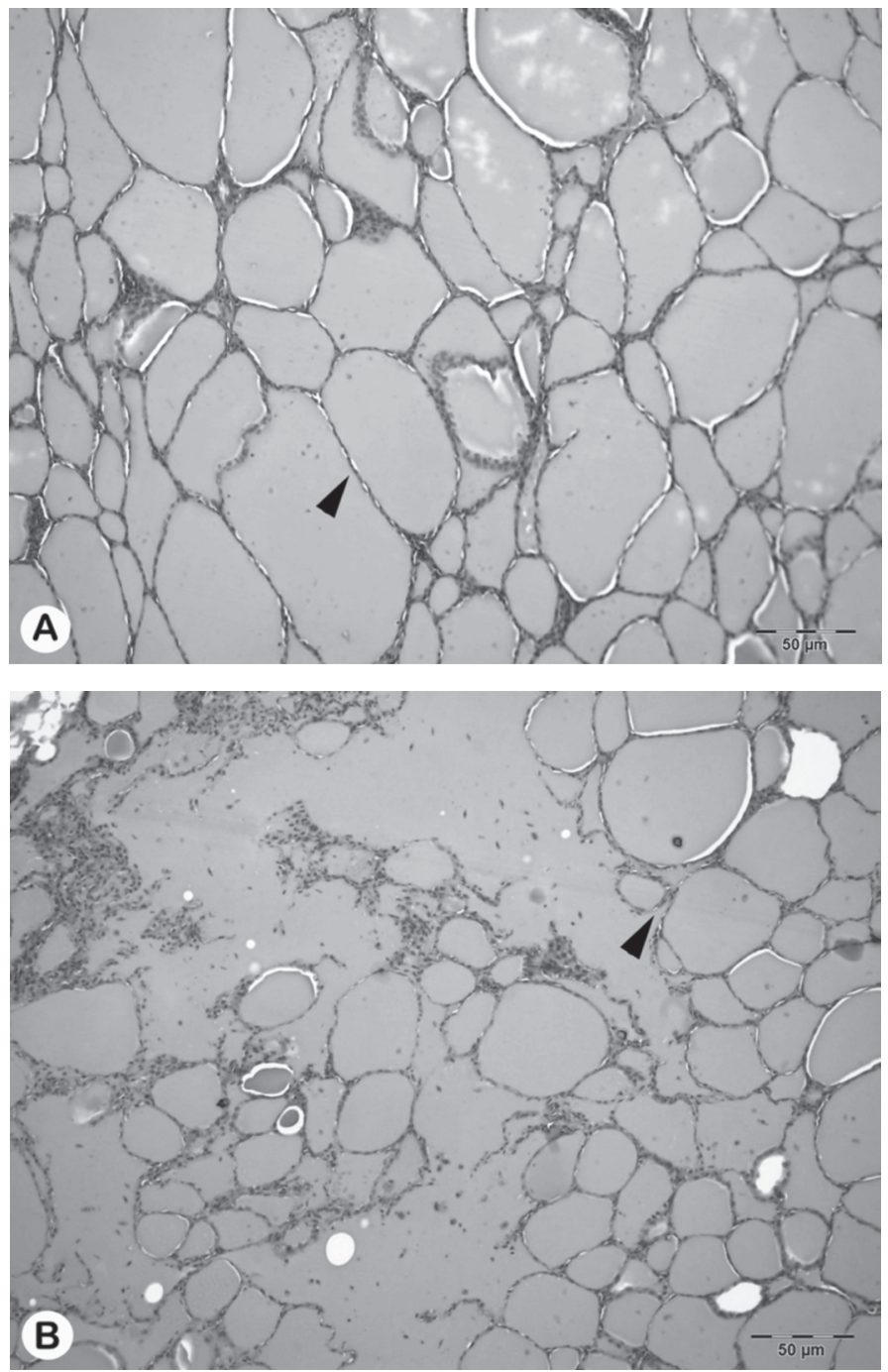

Figure 3 - Large colloid areas with lost follicular structure scattered in the parenchyma and interfollicular area (arrowhead) (H\&E) (Panel A), and restoration of the thyroid gland to normal (arrowhead) (H\&E) (Panel B) (Humic Acid Substances + Lead Group).

was selected in the present experiment in order not to cause mortality, but to cause toxicity within 10 days (Vangris and Mare, 1974). Accordingly, mortality was not recorded, but the elevation of plasma Pb level was evident (Table 1). The changes in plasma Pb levels were associated with changes with the plasma levels of thyroid gland hormones (Table 1).

Lead adversely affects the production, secretion, and biological activities of thyroid and stress hormones and of hormone-related metabolism (Zacharewski, 1998). In the present study, Pb poisoning partially affected the thyroid hormones (Table 1), which may be related to the duration and level of $\mathrm{Pb}$ ingestion. Ibrahim et al. (2012) showed that lead acetate ingestion did not cause any significant reduction of plasma $\mathrm{T}_{4}$ and $T_{3}$ levels. Similarly, in a study with 58 male gas station attendants and automobile mechanics with occupational exposures to high $\mathrm{Pb}$ levels, mean $\mathrm{T}_{3}$ and $\mathrm{T}_{4}$ levels did not differ (Singh et al., 2000). On the other hand, Robins et al. (1983) reported reduction of serum $\mathrm{T}_{4}$ and $\mathrm{FT}_{4}$ levels in humans exposed to excessive $\mathrm{Pb}$ levels. Dundar et al. (2006) evaluated the long-term and low-level $\mathrm{Pb}$ exposure among young individuals, and reported a negative correlation between blood lead and $\mathrm{FT}_{4}$ levels, but no changes in TSH and $\mathrm{FT}_{3}$ levels. In another study, high $\mathrm{FT}_{3}$ level and low TSH level in the group of patients poisoned with lead compared with the control group were reported (YIlmaz et al., 2012). When $\mathrm{Pb}$ concentration exceeds $52 \mu \mathrm{g} / \mathrm{dL}$, it triggers TSH secretion from the pituitary gland (Singh et al., 2000). In agreement with the present study, TSH level increased among workers exposed to lead (Gustatson et al., 1989; Lopez et al., 2000).

Lead can cause degenerative changes, satellitosis, neuronal vacuolation, neuronophagia, inflammatory changes and degenerative disorders in the nervous system, inflammatory cell infiltration and cytoplasmic vacuolation in the liver and kidneys (Taib et al., 2004; Ozsoy et al., 2011; Shalan et al., 2005). Degenerative changes, inflammatory cell infiltration, and interstitial connective tissue proliferation in the thyroid gland, indicating hypothyroidism, were observed in the present study (Figure 2).

Many agents, including vitamin C and L-carnitine, are applied for $\mathrm{Pb}$ poisoning treatment (Shaban ElNeweshy and Said El-Sayed, 2011; Flora et al., 2003). HAS are reported to alleviate abnormal thyroid hormone secretion and to act as immunomodulators (Laurberg et al., 2003). Nonetheless, HAS have multifunctional characteristics, such as to be able bind to metal ions to form chelates (Schnitzer and Khan, 1972). In the present study, dietary HAS supplementation partially alleviated feed intake and egg production reductions by $17.7 \%$ and $23.8 \%$, respectively (data not shown) and reduced serum $\mathrm{Pb}$ level by $16.4 \%$ (Table 1) compared with the hens exposed to $\mathrm{Pb}$ poisoning and not supplemented. Moreover, it reduced serum TSH to normal levels (Table 1), which could be explained but its protective effects on the parenchymal cells of the thyroid gland. In addition to forming chelates with heavy metals, HAS has anti-inflammatory effects. The thyroid tissue showed similar, but less severe lesions when hens were supplemented with HAS (Figure 3).

In conclusion, in hens experimentally poisoned with $\mathrm{Pb}, \mathrm{FT}_{3}$ and $\mathrm{FT}_{4}$ levels did not change, but TSH level increased by $167 \%$. The increase in serum Pb and TSH levels of hens exposed to $\mathrm{Pb}$ poisoning was partially and completely normalized, respectively, by dietary HAS supplementation, and were accompanied by the 
Sahin A, Iskender $\mathrm{H}$, Terim Kapakin KA, Altinkaynak K, Hayirli A, Gonultas A, Kaynar O
The Effect of Humic Acid Substances on the Thyroid Function and Structure in Lead Poisoning recovery of the degenerative changes observed in the thyroid gland. These results suggest that HAS may bind to heavy metals and play a role in the recovery of thyroid gland structure and function.

\section{Conflict of Interest Statement}

The authors declare that there are no conflicts of interest.

\section{REFERENCES}

Al-Saleh IAS. The biochemical and clinical consequences of lead poisoning. Medicinal Research Review 1994;14(4):415-486.

Burger AG. Environment and thyroid function. The Journal of Clinical Endocrinology and Metabolism 2004;89(4):1526-1528.

Cullent MR, Kayne RD, Robins JM. Endocrine and reproductive dysfunction in men in association with occupational inorganic lead intoxication. Archives of Environmental Health 1984;39(6):431-440.

Dundar B, Oktem F, Arslan MK, Delibas N, Baykal B, Arslan C, et al. The effect of long-term low dose lead exposure on thyroid function in adolescents. Environmental Research 2006;101(1):140-145

Elwood PC, Gallacher JEJ, Phillips KM, Davies BE, Toothill C. Greater contribution to blood lead from water than from air. Nature 1984;310(5973):138-140.

Fan TW, Lane AN, Chekmenev E, Wittebort RJ, Higashi RM. Synthesis and physico-chemical properties of peptides in soil humic substances. Journal of Peptide Research 2004;63(3):253-264.

Flora SJ, Pande M, Mehta A. Beneficial effect of combined administration of some naturally occurring antioxidants (vitamins) and thiol chelators in the treatment of chronic lead intoxication. Chemico-Biological Interactions 2003;145(3):267-280.

Gillis BS, Arbieva Z, Gavin IM. Analysis of lead toxicity in human cells. BMC Genomics 2012;13:344-356.

Gustatson A, Hedner P, Schutz A, Skerfving S. Occupational lead exposure and pituitary function. International Archives of Occupational and Environmental Health 1989:61(4):277-281.

Hilliard EP, Poole DBR, Collins JD. Accidental lead intoxication of cattle:Further evidence of an interference in heme biosynthesis. British Veterinary Journal 1973;129(6):389-403

Ibrahim NM, Eweis EA, El-Beltagi HS, Abdel-Mobdy YE. Effect of lead acetate toxicity on experimental male albino rat. Asian Pacific Journal of Tropical Biomedicine 2012;2(1):41-46.

Islam KMS, Schuhmacher A, Gropp JM. Humic acid substances in animal agriculture. Pakistan Journal of Nutrition 2005;4(3):126-134.

Laurberg P, Andersan S, Pedersen IB, Ovesen L, Knudsen N. Humic substances in drinking water and the epidemiology of thyroid disease. BioFactors 2003:19(3-4):145-153.

Lavicoli I, Carelli G, Stanek EJ, Castellino N, Calabrese EJ. Effects of low doses of dietary lead on red blood cell production in male and female mice. Toxicology Letters 2003;137(3):193-199.

Lopez CM, Pineiro AE, Nunez N, Avagnina AM, Villaamil EC, Roses OE. Thyroid hormone changes in males exposed to lead in the Buenos Aires area (Argentina). Pharmacological Research 2000;42(6):599-602.
Lyn Patrick ND. Lead toxicity part II: The role of free radical damage and the use of antioxidants in the pathology and treatment of lead toxicity. Alternative Medicine Review 2006;11(2):114-127.

Lynch GP, Smith DF, Fishcr M. Physiological responses of calves to cadmium and lead. Journal of Animal Science 1976;42(2):410-421.

NRC. Nutrient requirements of poultry. Washington: National Research Council; 1994

Ozsoy SY, Ozsoy B, Ozyildiz Z, Aytekin I. Protective effect of L carnitine on experimental lead toxicity in rats:a clinical, histopathological and immunohistochemical study. Biotechnic Histochemistry 2011;86(6):436-443.

Robins JM, Cullen MR, Connors BB, Kayne RD. Depressed thyroid indexes associated with occupational exposure to organic lead. Archives of Internal Medicine 1983:143(2):220-224.

Roper WL. Preventing lead poisoning in young children. Atlanta: Centers for Disease Control; 1991. Available from: http://www.nmic.org/ nyccelp/medical-studies/CDC-Preventing-lead-poisoning-10-91.pdf.

SAS. SAS user's guide: statistics. 9th ed. Cary: Statistical Analysis System Institute; 2002

Schnitzer M, Khan SU. Humic substances in the environment. New York: Marcel Dekker; 1972

Shaban El-Neweshy $M$, Said El-Sayed $Y$. Influence of vitamin C supplementation on lead-induced histopathological alterations in male rats. Experimental and Toxicologic Pathology 2011;63(3):221-227.

Shalan MG, Mostafa MS, Hassouna MM, Hassab El-Nabi SE, El Refaie A. Amelioration of lead toxicity on rat liver with vitamin $C$ and silymarin supplements. Toxicology 2005;206(1):1-15

Singh B, Chandran V, Bandhu HK, Mittal BR, Bhattacharya A, Jindal SK, et al. Impact of lead exposure on pituitary-thyroid axis in humans. Biometals 2000;13(2):187-192.

Smith MA. Lead in history. In: Ansdown R, Yule W, editors. The lead debate: the environmental toxicology and child health. London: Croom Helm; 1984. p. 7-24.

Szkudlinski MW, Fremont $\mathrm{V}$, Ronin C, Weintraub BD. Thyroid stimulating hormone and thyroid-stimulating hormone receptor structure-function relationships. Physiological Reviews 2002;82(2):473-502

Taib NT, Jarrar BN, Mubarak M. Ultrastructural alterations in hepatic tissues of white rats (Rattusnorvegicus) induced by lead experimental toxicity. Saudi Journal of Biological Sciences 2004;11(1):11-20

Tong S, Von Schirnding YE, Prapamontol T. Environmental lead exposure: a public health problem of global dimensions. The Bulletin of the World Health Organization 2000;78(9):1068-1077.

Vengris VE, Mare CJ. Lead poisoning in chickens and the effect of lead on interferon and antibody production. Canadian Journal Comparative Medicine 1974;38(3):328-335.

Yilmaz H, Keten A, Karacaoğlu E, Tutkun E, Akçan R. Analysis of the hematological and biochemical parameters related to lead intoxication. Journal of Forensic and Legal Medicine 2012;19(8):452-454.

Zacharewski T. Identification and assessment of endocrine disruptors limitations of in vivo and in vitro assays. Environmental Health Perspectives 1998:106:577-582. 
